\title{
Testing the embedding effect in the valuation of lagoon recovery
}

\author{
Guillermo Donoso ${ }^{1}$, José Cancino ${ }^{1}$, and Susana Villar ${ }^{2}$ \\ ${ }^{1}$ Departamento de Economía Agraria, Facultad de Agronomía e Ingeniería Forestal. Pontificia Universidad \\ Católica de Chile. Casilla 306-22, Santiago, Chile. \\ ${ }^{2}$ Departamento de Mecanización y Energía, Facultad de Ingeniería Agrícola. Universidad de Concepción. \\ Casilla 537, Chillán, Chile.
}

\begin{abstract}
G. Donoso H., J. Cancino, and S. Villar. 2010. Testing embedding the effect in the valuation of lagoon recovery. Cien. Inv. Agr. 37(1): 103-111. The contingent valuation method was employed to assess the benefits of recovering the Laguna Grande de San Pedro de La Paz in Chile's Bío-Bío region and to analyze the possible existence of an embedding effect. Our results indicate that there is not a perfect part-whole valuation effect and that there is an imperfect substitution relationship between the two analyzed projects. In addition, when assessing the joint construction project of a main sewer and a recreation park on the north hillside of the lagoon, we determined that households were willing to pay an average monthly amount of $\$ 6,114$ for the associated benefit of the environmental improvement. This amount would contribute $\$$ $358,977,396$ per month to the project and a total value of $\$ 4,307,728,752$. Additionally, the separate valuation of the two projects resulted in an amount of $\$ 3,290,635,524$ for the main sewer and $\$ 2,484,518,138$ for the recreation park. The absence of part-whole valuation effect may be explained by the precautions adopted in the survey's design and application, based on the review and analysis of prior studies.
\end{abstract}

Key words: Contingent valuation, economic value, embedding effect, part-whole effect, scope insensitivity.

\section{Introduction}

In Chile, a growing interest has risen in recent decades to achieve appropriate environmental management and an optimal allocation of human and financial resources towards the care of the natural environment. Therefore, to obtain efficient indicators for the design of management policies of environmental resources, the employment of economic valuation methodologies has increased in recent years (Del Saz Sala-

Received 24 April 2009. Accepted 19 May 2009. Corresponding author: gdonosoh@uc.cl zar et al., 2009; Venkatachalam, 2004; Shackley and Dixon, 2000; Perman et al., 1999; Carson et al., 1997; Melo and Donoso, 1995; Brown and Duffield, 1995; Hoevenagel, 1994; Azqueta, 1994; Bojö et al., 1992; Pearce and Turner, 1990; Mitchell and Carson, 1989).

In the event of a nonexistent market for these environmental goods, the contingent valuation method (CVM) allows for the use of a hypothetical market to obtain the value of the benefits perceived by the individuals. This method directly estimates the willingness of citizens to pay for the modified conditions of an environmental good and has been widely used to quantify monetary benefits and environmental dam- 
ages (Venkatachalam, 2004; Shackley and Dixon, 2000; Carson et al., 1997; Melo and Donoso, 1995; Hoevenagel, 1994; Azqueta, 1994; Mitchell and Carson, 1989).

This method is frequently used because it is usually the only feasible valuation method (for example, when it is impossible to establish a link between the environmental good and the consumption of a private good) in addition to being the only valuation method that allows for the measurement of use and non-use values (Venkatachalam, 2004; Champ, 2002; Carson et al., 1997; Brown and Duffield, 1995; Bojö et al., 1992).

However, a series of biases might rise in the application of CVM, which must be considered (Venkatachalam, 2004; Perman et al., 1999; Azqueta, 1994; Arrow et al., 1993; Pearce and Turner, 1990; Mitchell and Carson, 1989). The biases are divided into instrumental (startingpoint bias, form of payment, information, interviewer and order) and non-instrumental (hypothesis bias and strategic bias).

The embedding effect, or order bias, presents itself when a specific good receives a different valuation when it is valued independently or as a component of a good to which it belongs. This effect results from category differences (when a good is a component of a larger good), geographic scales (when these goods represent different geographic areas or territories), or time scales (when the willingness to pay is defined by different temporal payment schemes) (Clark and Friesen, 2008; McDaniels et al., 2003; Svedsäter, 2000; Vial et al., 1998; Cerda et al., 1997; Carson and Mitchell, 1995; Brown and Duffield, 1995; Azqueta, 1994; Loomis et al., 1993).

Research on the embedding effect can be traced back to a pioneering study by Kahneman and Knetsch (1992). Several studies have since been conducted with the objective to determine the existence of the partial and/or total existence of that effect (Clark and Friesen, 2008; McDaniels et al., 2003; Svedsäter, 2000; Vial et al., 1998; Cerda et al., 1997; Carson and Mitchell, 1995; Brown and Duffield, 1995; Loomis et al., 1993).
Psychologists also recognize the relevance of order bias (Clark and Friesen, 2008). Svedsäter (2000) has indicated that environmental goods receive a lower valuation when they are presented as a whole rather than individually.

On the other hand, Brown et al. (2008) verified that the valuation reliability of public or private goods increases as the polled person understands the problem that is being valued. This study also indicates that valuation tends to be more precise in the case of private goods than in public goods.

The study by Carson and Mitchell (1995) indicates that the term embedding has been mistakenly used by researchers describing benefits or failures found in the different types of relations between goods. They propose a new concept and testing method called "nesting and sequencing." The nesting effect arises when two goods correspond to a subset of another good (nested goods). Sequencing is present when the valuation of a good, which is part of a group, is subject to the order in which it is evaluated with respect to the other goods. Additionally, these authors recommend careful attention to potential specification errors in survey design and the use of a plausible market as a hypothetical scenario.

Clark and Friesen (2008) indicate that the hypothetical values answered by the polled person in a nested sequence of environmental goods are sensitive and depend on the order in which these goods are presented, concluding that the small packs of goods generally receive a better valuation if they are presented first rather than at the end. Additionally, in a valuation study of air quality in Poland, it was found that the embedding effect decreases when a system of dichotomic questions is used (Parry and Mendelsohn, 2005).

Kahneman and Knetsch (1992) conducted a phone survey to three samples of adults in the city of Vancouver to test the embedding effect. In the first sample, questions about the willingness to pay for the improvement on environmental services were included. Then, polled people were asked specifically how much of that amount they would spend solely to repair disas- 
ters. Finally, they were asked how much of this amount would be spent on a larger team of rescue-trained personnel. For the second sample, only the two last questions were asked, and only the last question was considered for the third sample. The results showed the existence of an embedding effect.

Similarly, Loomis et al. (1993) studied the willingness to pay to preserve three areas of state property in southeastern Australia, using mail surveys with closed and dichotomic questions and describing the areas through maps. These authors proved the existence of the embedding effect and found values lower than the values determined by Kahneman and Knetsh (1992).

For the Chilean case, the study by Vial and Cerda (1996) used the CVM and found the existence of an embedding effect in the valuation of the protection of two wild areas, one being part of the other, located in the sector of Nevados de Chillán, in the Bío-Bío region of Chile. Two types of personal surveys were applied to two homogeneous samples from the city of Chillán. The first survey estimated participants' willingness to pay (WTP) for an area larger than 45,000 ha in the sector and, after the participants agreed, the researchers estimated their willingness to pay for the use of a smaller area of 3,500 ha, called Shangri La, which was part of the larger area. The second survey only asked participants about the WTP for the smaller area. The results indicate that there was no evidence of an embedding effect, although the possibility of a partial embedding was not discarded.

The existence of the embedding effect raises doubts on the validity of the CVM responses and results, as it might not reveal the value that people assign to a specific good but what their contribution would be to a "good cause" as a moral obligation. This potential effect might affect decision-making in the field of public goods, as it does not allow for a comparison between two projects (Loomis et al., 1993; Kahneman and Knetsch, 1992).

Laguna Grande de San Pedro, located in the northwestern part of the Nahuelbuta mountains $\left(36^{\circ} 51^{\prime} \mathrm{S}\right.$ and $\left.73^{\circ} 06^{\prime} \mathrm{W}\right)$, presents a high degree of deterioration due to an eutrophication process, which corresponds to the enrichment of waters with nutrients and the consequent increase of seaweeds and macrophyte population, deterioration of water quality, and other undesired changes that interfere with its use (Parra, 1989). This phenomenon has been accelerated by the emissions of sewage and water rain evacuation into the lagoon. Additionally, the ecosystems of the Laguna Grande de San Pedro shores present a high degree of deterioration because of the illegal disposal of domestic residues.

This situation has reduced the use of the lagoon for different recreational practices such as fishing, swimming, nautical sports and walks. In order to solve this problem, two possible projects are proposed. The first project corresponds to the construction of a collector pipe to collect rain water and sewage waters, preventing them reaching the lagoon and reducing the advance of the eutrophication process. The second project consists of the development and construction of a recreational park on the northern shore to recover the shore ecosystems, which include sport areas, grass, children attractions, rustic tables and native trees.

The objective of this paper is to research the existence of an embedding effect. For this purpose, the benefits of the recovery plan of Laguna Grande of San Pedro de La Paz are valued using the method of contingent valuation as a case study.

\section{Materials and methods}

In order to value the proposed projects, we use the CVM. In a first stage, the study universe was determined to comprise the municipalities and the city of San Pedro de la Paz in the province of Concepción, which consists of 81,808 urban houses according to the last 2002 Census (INE, 2003). A pre-survey was applied using the urban house as a sampling unit and employing the census districts defined in INE (2005), the number of houses per district and the income level of the households. The objective was to test the survey questionnaire and to establish the empirical distribution of willingness to pay. 
Table 1 presents the relations that can exist between the values of two goods (see Hoehn, 1991 and Brown and Duffield, 1995). The values assigned to goods $A, B$ and $C$, are represented by $\mathrm{v}(\mathrm{A}), \mathrm{v}(\mathrm{B})$ and $\mathrm{v}(\mathrm{C})$, respectively, where good $\mathrm{C}$ corresponds to the combination of goods $\mathrm{A}$ and B. Additionally, v(A)' corresponds to the value assigned to good $\mathrm{A}$ when it is considered a part of good C. Using this symbology, Table 1 shows the basic relations that economic theory identifies between two goods (complementarity, neutrality and perfect and imperfect substitution), in addition to those relationships that may arise when a total or partial embedding effect is present. In the first case, where the goods correspond to imperfect substitutes with perfect embedding, the polled person perceives the value of good A when it is considered part of $\mathrm{C}$ as being less than that of good A; that is, $\mathrm{v}(\mathrm{A})^{\prime}<\mathrm{v}(\mathrm{A})=\mathrm{V}(\mathrm{C})$. However, in the second case of imperfect substitution with partial embedding, the polled person interprets $\operatorname{good} \mathrm{A}$ as a fraction of $\mathrm{C}$ so that $\mathrm{V}(\mathrm{A})^{\prime}<\mathrm{v}(\mathrm{A})$ $<\mathrm{v}(\mathrm{C})$.
$\mathrm{v}(\mathrm{C})-\mathrm{v}(\mathrm{B})$. As a result, if goods $\mathrm{A}$ and $\mathrm{B}$ are imperfect substitutes, then $\mathrm{v}(\mathrm{A})^{\prime}=\mathrm{V}(\mathrm{A})<\mathrm{V}(\mathrm{C})<\mathrm{V}(\mathrm{A}$ $+\mathrm{B})$. On the contrary, they are imperfect complements if $\mathrm{v}(\mathrm{A})^{\prime}=\mathrm{V}(\mathrm{A})<\mathrm{V}(\mathrm{C})>\mathrm{V}(\mathrm{A}+\mathrm{B})$. The third method, widely used in different empirical studies, estimates $\mathrm{v}(\mathrm{C})$ and then asks what proportion of that value is assigned to good A ( $\left(\mathrm{A}(\mathrm{A})^{\prime}\right)$.

The present study uses the third procedure proposed by Brown and Duffield (1995). Three different surveys were applied at each sample point (100 surveys from each type). As a result, 300 surveys were applied in total. The difference between the three survey formats corresponded to the type of project they considered. Survey A presented the construction of the collector pipe (project A), survey B considered the park in the North shore of the lagoon (project B), and survey $\mathrm{C}$ referred to the joint execution of both projects (project $\mathrm{C}$ ).

Commonly used methodologies that study the existence of embedding effect were considered in the survey design (Clark and Friesen, 2008;

Table. 1. Possible relationships among goods and their assessed economic values.

\begin{tabular}{|c|c|c|c|c|c|c|c|}
\hline \multirow{2}{*}{$\begin{array}{l}\text { Relationship between goods A and B } \\
\text { Neutrality }\end{array}$} & \multicolumn{7}{|c|}{ Relationship between the values of goods $\mathrm{A}, \mathrm{B}$ and $\mathrm{C}^{1}$} \\
\hline & $v(A)+v(B)$ & $=$ & $\mathrm{v}(\mathrm{C})$ & $>$ & $\mathrm{v}(\mathrm{A})$ & $=$ & $\mathrm{v}(\mathrm{A})^{\prime}$ \\
\hline Complementarity & $v(A)+v(B)$ & $<$ & $\mathrm{v}(\mathrm{C})$ & $>$ & $\mathrm{v}(\mathrm{A})$ & $=$ & $\mathrm{v}(\mathrm{A})^{\prime}$ \\
\hline Perfect substitution & $v(A)+v(B)$ & $>$ & $\mathrm{v}(\mathrm{C})$ & $=$ & $\mathrm{v}(\mathrm{A})$ & $=$ & $\mathrm{v}(\mathrm{A})^{\prime}$ \\
\hline Imperfect substitution & $v(A)+v(B)$ & $>$ & $\mathrm{v}(\mathrm{C})$ & $>$ & $\mathrm{v}(\mathrm{A})$ & $=$ & $\mathrm{v}(\mathrm{A})^{\prime}$ \\
\hline Imperfect substitution with perfect embedding & $v(A)+v(B)$ & $>$ & $\mathrm{v}(\mathrm{C})$ & $=$ & $\mathrm{v}(\mathrm{A})$ & $>$ & $\mathrm{v}(\mathrm{A})^{\prime}$ \\
\hline Imperfect substitution with partial embedding & $v(A)+v(B)$ & $>$ & $\mathrm{v}(\mathrm{C})$ & $>$ & $\mathrm{v}(\mathrm{A})$ & $>$ & $\mathrm{v}(\mathrm{A})^{\prime}$ \\
\hline
\end{tabular}

$1 \mathrm{~V}(\mathrm{~A})$ and $\mathrm{V}(\mathrm{B})$ represent the value of goods $\mathrm{A}$ and $\mathrm{B}$, respectively. $\mathrm{V}(\mathrm{C})$ corresponds to the value of goods A and B together. Finally, $\mathrm{V}(\mathrm{A})$ represents the value assigned to good A when it is considered part of the joint good C. Source: Adapted from Hoehn (1991) and Brown and Duffield (1995).

There are three alternative procedures in order to estimate v(A)' (Brown and Duffield, 1995). In the first procedure, the polled person is asked to value only good $\mathrm{A}$, in which case $\mathrm{v}(\mathrm{C})$ is essentially assigned to good B. In this case, v(A)' is assumed to be a fraction of $\mathrm{v}(\mathrm{C})$, which can be estimated by independently valuing good $\mathrm{A}$. The second procedure, known as the residual procedure, consists of estimating $\mathrm{v}(\mathrm{B})$ by asking their willingness to pay (WTP) without informing the existence of good A. Once $\mathrm{v}(\mathrm{C})$ is estimated, v(A)' is calculated as the difference
Vial and Cerda, 1996; Brown and Duffield, 1995; Loomis et al., 1993). Specifically, the first part of the questionnaire presents questions about the level of knowledge of the lagoon's situation and the activities related to the lagoon, in addition to the number of visits during the last two years.

The following section of the survey contained the valuation questions using a dichotomic format without a follow-up (Herriges and Shogren, 1996). In this section, the polled person was 
asked if he was willing to contribute with the amount presented on a card once the polled person had read a document describing the project and showing photos of the place. The amounts included in the survey were determined by the empirical distribution of the willingness to pay employing the method proposed by Boyle et al. (1988). The form of payment used was a monthly charge included in the municipal cleaning bill; this was the most accepted payment form indicated in the pre-survey.

In the format $\mathrm{C}$ of the survey, a specific question to test for the existence of an embedding effect was included. When the polled person was willing to pay for the joint execution of the two projects, they were requested to assign a percentage of that amount to the collector pipe construction project. Additionally, the polled person was asked for the reasons why they are willing to contribute to an environmental project as the one presented in the survey. The reasons considered in the questionnaire were recreational use, the option of future visits, the existence value, the preservation for future generations proposed by Walsh et al. (1984) and Loomis et al. (1993), and contributing to a good cause, which was pointed out by Kahneman and Knetsh (1992).

The third and last section of the survey collected personal data of the polled person such as address, age, number of family members, studies, occupation and income level. The level of study ranges from incomplete elementary education to complete university education with nine levels to choose from; 17 levels were used for occupation, and 12 levels were used for income. The income levels were determined considering the average levels of the monetary income of the different deciles of the study area.

The WTP was estimated using the procedure described by Cameron and James (1987), who propose that the true willingness to pay (WTP*) is given by

$\mathrm{WTP} *=\mathrm{X}^{*} \beta^{*}+\varepsilon^{*}$,

where WTP* is the true WTP, $\mathrm{X}^{*}$ is a matrix that contains the socioeconomic variables of the polled people, $\beta^{*}$ is a vector of the estimated parameters, and $\varepsilon^{*}$ is the error term.
When the response to a proposed payment of a WTP level given by BID $_{j}$ is yes, we know that $\mathrm{WTP}^{*} \geq \mathrm{BID}_{\mathrm{j}}$. When the answer to the same question is no, we know that WTP* $<\mathrm{BID}_{\mathrm{j}}$. As a result, the probability of obtaining an affirmative response for a determined $\mathrm{BID}_{\mathrm{j}}$ is

$P(D=1)=P\left(B I D-X^{*} \beta^{*} \leq \varepsilon^{*}\right)$.

As a result, the probability that the offered BID $_{j}$ is accepted can be rewritten as

$P(D=1)=F(X \gamma) \quad$ o $\quad P(D=0)=1-F(X \gamma)$,

where $\mathrm{F}(\mathrm{X} \gamma)$ is the $\mathrm{WTP}^{*}$ distribution function evaluated at $\mathrm{X} \gamma, \mathrm{X}=\left[\mathrm{BID}_{\mathrm{j}} \mathrm{X}^{*}\right]$ and $\gamma=\left[\alpha \beta^{*}\right]^{\prime}$, where $\alpha$ is the parameter coefficient associated to the willingness to pay. Cameron and James (1987) demonstrated that $\alpha=-1 / \sigma, \beta=\beta^{*} / \sigma$ and that $\beta^{*}=-\beta / \alpha$.

The parameters of (3) were estimated by maximizing the logarithm of the likelihood function given by

$$
\begin{aligned}
& \log \mathrm{L}=\left(\sum_{\mathrm{i}=1}^{\mathrm{n}} \mathrm{P}_{\mathrm{i}} \log [\mathrm{P}(\text { yes })]\right)+\left(\sum_{\mathrm{i}=1}^{\mathrm{n}}\left(1-\mathrm{P}_{\mathrm{i}}\right) \log [\mathrm{P}(\text { no })]\right. \\
& =\left(\sum_{\mathrm{i}=1}^{\mathrm{n}} \mathrm{P}_{\mathrm{i}} \log \left[\frac{1}{\left(1+\mathrm{e}^{-\mathrm{X} \gamma}\right)}\right]\right)+\left(\sum_{\mathrm{i}=1}^{\mathrm{n}}\left(1-\mathrm{P}_{\mathrm{i}}\right) \log \left[\frac{\mathrm{e}^{-\mathrm{X} \gamma}}{\left(1+\mathrm{e}^{-\mathrm{X} \gamma}\right)}\right]\right)
\end{aligned}
$$

where $\mathrm{P}_{\mathrm{i}}$ takes the values of zero or one depending on the answer of the polled person.

In order to verify the existence of a perfect embedding effect, three tests are carried out. It is first necessary to test whether the sum of the valuations estimated separately for each project, the collector pipe (v(A)) and the park (v(B)), is higher than the estimated value of the two together $(\mathrm{v}(\mathrm{C}))$. Second, it is necessary to prove that $v(C)$ is equal to $v(A)$. Finally, the third test is a test of the hypothesis that $\mathrm{v}(\mathrm{A})$ is higher than the valuation of the same project $A$ when it is evaluated as part of project $\mathrm{C}$, that is, $\mathrm{v}(\mathrm{A})$ $>\mathrm{v}(\mathrm{A})$ '. These hypotheses are tested by a means test of the values obtained in samples A, B and $\mathrm{C}$, where the equality of variances was previously tested. 
In order to compare the estimated models, a Chi-squared test was employed to assess the null hypothesis that all of the estimated coefficients, except the constant, are simultaneously equal to zero. In addition, the proportion of correct predictions of each model was determined.

Then, to compare the estimated $\mathrm{WTP}_{\mathrm{C}}$ value with the sum of the mean estimated values of $\mathrm{WTP}_{\mathrm{A}}$ and $\mathrm{WTP}_{\mathrm{B}}$, the $\mathrm{WTP}_{\mathrm{B}}$ was calculated with the sample data of survey A and the $\mathrm{WTP}_{\mathrm{A}}$ with the data of sample B. This is necessary, as the estimates of the $\mathrm{WTP}_{\mathrm{A}}$ and $\mathrm{WTP}_{\mathrm{B}}$ from surveys $A$ and $B$, respectively, are from a different number of polled persons, which invalidates the direct sum of these values.

Finally, the embedding hypothesis was tested by estimating the mean values assigned to the collector pipe project when it is considered as part of the two projects as a whole.

\section{Results and discussion}

Once the surveys with protest answers were eliminated from the sample, 75, 73 and 76 observations were used for surveys A, B and C, respectively. In general, the protest answers were due to the view that the project should be executed by state agencies linked to the municipality of San Pedro de La Paz and not to the municipality of Concepción. Additionally, by means of a t-test, the three samples were found to be homogeneous in their variables with a $95 \%$ level of confidence, considering that the variances were different as was previously determined by an $\mathrm{F}$ test.

The variables finally included in each regression are those for which the maximum likelihood ratio test indicated that the estimated parameter coefficients are significant and that the null hypothesis that the restricted parameters are equal to zero was accepted at the 5\% level of significance. The final estimated models are the following:

\section{Model A}

$$
\Delta \mathrm{V}=\alpha_{0}+\mathrm{B}_{0} \mathrm{OWTP}+\mathrm{B}_{1} \mathrm{KNOW}+\mathrm{B}_{2} \mathrm{INC},
$$

Model B
$\Delta \mathrm{V}=\alpha_{0}+\mathrm{B}_{0} \mathrm{OWTP}+\mathrm{B}_{1} \mathrm{KNOW}+\mathrm{B}_{2} \mathrm{INC}$,

and

\section{Model C}

$\Delta \mathrm{V}=\alpha_{0}+\mathrm{B}_{0} \mathrm{OWTP}+\mathrm{B}_{1} \mathrm{AGE}+\mathrm{B}_{2} \mathrm{INC}$.

where OWTP corresponds to the offered willingness to pay presented in each survey (Chilean pesos); KNOW corresponds to the level of knowledge of the study area, a binary variable (takes the value of 1 when the polled person knows the area and 0 in any other case); INC is the level of family income (Chilean pesos); and AGE is the age of the polled person.

The estimated parameters are presented in Table 2. The results indicate that the estimated OWTP coefficient is significant at the $1 \%$ level of significance and negative, which is consistent with the theory and valuation literature; as a result, the probability that the polled person accepts the offered willingness to pay decreases as the proposed amount increases. The estimated coefficient of KNOW is positive but not significant. The parameter of AGE is negative, implying that probability of accepting the offered willingness to pay decreases as the age of the polled person increases. Finally, the parameter estimate of INC is significant at the 5\% level of significance and is positive, showing that when family income is higher, the probability of accepting the offered willingness to pay increases. The Chi-squared test results, presented in Table 2, indicated that all of the estimated models are globally significant at the $5 \%$ level of significance. Additionally, the proportion of wrong predictions corresponds to a percentage fluctuating between 15 and $20 \%$.

The mean willingness to pay (WTP) of each sample was calculated using the estimated parameters presented in Table 2. In this case, the mean WTP for sample $\mathrm{C}\left(\mathrm{WTP}_{\mathrm{C}}\right)$ reached a value of $\$ 6,114$ (with a standard deviation of 1.52). Considering that the municipalities of Concepción and San Pedro de la Paz have 58,714 urban houses, the total WTP for both of the proposed projects is $\$ 4,307,728,752$. Similarly, the calculated willingness to pay for projects $\mathrm{A}\left(\mathrm{WTP}_{\mathrm{A}}\right)$ 
and $\mathrm{B}\left(\mathrm{WTP}_{\mathrm{B}}\right)$ are $\$ 4,670$ (with a standard deviation of 2.75) and $\$ 3,526$ (with a standard deviation of 2,01), respectively. Therefore, the total values of WTP for projects A and B are $\$ 3,290,635,524$ and $\$ 2,484,518,138$, respectively. These estimated WTP are significantly different at a 5\% level of significance. Therefore, the WTP for the two projects executed as a whole $\left(\mathrm{WTP}_{\mathrm{C}}\right)$ is less than the sum of the WTP for each individual project $\left(\mathrm{WTP}_{\mathrm{A}}+\mathrm{WTP}_{\mathrm{B}}\right)$. In addition, the WTP for the collector pipe project $\left(\mathrm{WTP}_{\mathrm{A}}\right)$ is higher than that for the park project $\left(\mathrm{WTP}_{\mathrm{B}}\right)$. These results indicate that the proposed projects, a collector pipe and a park, correspond to substitute goods. Additionally, as $\mathrm{WTP}_{\mathrm{C}}>$ $\mathrm{WTP}_{\mathrm{A}}$, it is possible to conclude that they are imperfect substitute goods (Table 1).

The mean WTP for project A is $\$ 5,336$, when it is valued as part of $\mathrm{C}\left(\mathrm{WTP}_{\mathrm{A}}\right)$. However, $\mathrm{V}(\mathrm{A})$ and $\mathrm{V}(\mathrm{A})$ ' are not significantly different at the $5 \%$ level of significance; consequently, the presence of the perfect embedding is rejected. Therefore, projects $\mathrm{A}$ and $\mathrm{B}$ correspond to imperfect substitute goods without an embedding effect.

\section{Conclusions}

The estimated mean willingness to pay for the construction of a collector pipe and a recreational park on the north shore of Laguna Grande de San Pedro is $\$ 6,114$ a month per home. Therefore, the total WTP for these environmental projects is $\$ 4,307,728,752$. When both projects are considered separately, a total mean value of $\$ 3,290,635,524$ is obtained for the collector pipe project, and a total mean value of $\$ 2,484,518,138$ is obtained for the recreational park.

With regard to the objective of testing for the existence of perfect or partial embedding, the results allow for the rejection of the null hypothesis that there is an embedding effect. This result can be explained by the precautions adopted during the survey design and its application, derived from the revision and analysis of previous research.

Table 2. Parameters and indicators associated with estimated linear models.

\begin{tabular}{lccc}
\hline Item & Model A & Model B & Model C \\
\hline Constant & 0.5021 & 0.2206 & 4.4768 \\
& $(0.58)$ & $(0.20)$ & $(2.63)^{* * *}$ \\
Offered willingness to pay (OWTP) & -0.000601 & -0.001120 & -0.000990 \\
Knowledge (KNOW) & $(-2.44)^{* * *}$ & $(-3.23)^{* * *}$ & $(-3.06)^{* * *}$ \\
& 0.8977 & 1.6868 & \\
Income level (INC) & $(1.14)$ & $(1.48)$ & - \\
& 0.00000543 & 0.00000614 & 0.00000482 \\
Age & $(1.88)^{* *}$ & $(2.35)^{* *}$ & $(2.12)^{* *}$ \\
Logarithm of non-restricted likelihood function & -31.65 & & -0.00000661 \\
Logarithm of restricted likelihood function & -38.88 & -38.39 & $(-2.12)^{* *}$ \\
Chi-square (95\% of significance) & 14.46 & 28.89 & -27.81 \\
Number and percentage of wrong predictions & $15(20.0 \%)$ & $11(15.1 \%)$ & $13(17.1 \%)$ \\
Total Surveys & 75 & 73 & 76 \\
\hline T & & & 25.16 \\
\hline
\end{tabular}

T statistic in parentheses, ${ }^{* *}$ significant at $1 \%, * *$ significant at $5 \%$. 


\title{
Resumen
}

\begin{abstract}
G. Donoso H., J. Cancino y S. Villar. 2010. Evaluación del efecto incrustamiento, en la recuperación de una zona lacustre. Cien. Inv. Agr. 37(1): 103 - 111. A fin de valorar los beneficios del plan de recuperación de la Laguna Grande de San Pedro de La Paz, ubicada en la Región del Bío-Bío de Chile, se aplicó el método de valoración contingente, y se investigó la posible existencia de un efecto incrustamiento. Los resultados del estudio permiten rechazar la presencia del llamado efecto incrustamiento perfecto, y determinar que existe una relación de sustitución imperfecta entre los dos proyectos analizados. Además, al valorar el proyecto conjunto de construcción de un ducto colector y el de un parque recreativo en la ladera Norte de la laguna, se determinó una disposición a pagar media por el beneficio asociado a mejorar este bien ambiental de $\$ 6.114$ mensuales por hogar. Este monto reportaría al proyecto un valor mensual de $\$ 358.977 .396$ y un valor total de $\$ 4.307 .728 .752$. Por otro lado, al considerar ambos proyectos por separado se obtuvo una valoración equivalente a $\$ 3.290 .635 .524$, en el caso del ducto colector, y de $\$ 2.484 .518 .138$ para el parque recreacional. La ausencia de efecto incrustamiento se explicaría por las precauciones adoptadas en el diseño y aplicación de la encuesta, derivadas de la revisión y análisis de investigaciones efectuadas anteriormente.
\end{abstract}

Palabras clave: Efecto incrustamiento, efecto Todo-Parte, valoración contingente, valor económico.

\section{References}

Arrow, K., R. Solow, P. Portney, E. Leamer, R. Radner, and H. Schuman. 1993. Report of the National Oceanic and Atmospheric Administration Panel Contingente Valuation. Federal Register 58:4602-4614.

Azqueta, D. 1994. Valoración Económica de la Calidad Ambiental. McGraw-Hill, Madrid, España. 299 pp.

Bishop, R., and T. Heberlein. 1979. Measuring values of extramarket goods: Are indirect measures biased? American Journal of Agricultural Economics 61:926-930.

Bojö, J., K. Mäler, and L. Unemo. 1992. Environment and Development: An Economic Approach. Kluwer Academic Publishers, Dordrecht, The Netherlands. 211 pp.

Boyle, K., P. Welsh, and R. Bishop. 1988. Validation of empirical measures of welfare change: Comment. Land Economics 64:94-98.

Brown, T., and J. Duffield. 1995. Testing part-whole effects in contingent valuation of instream flow protection. Water Resources Research 31:23412351.

Brown, T., D. Kingsley, G. Peterson, N. Flores, A. Clarke, and A. Birjulin. 2008. Reliability of individual valuations of publics and private goods: choice consistency, response time, and preference refinement. Journal of Public Economics 92:1595-1606.

Cameron, T., and M. James. 1987. Efficient estimation Methods for "Closed Ended" contingent valuation surveys. Review of Economics and Statistics 69:269-276.

Carson, R., and C. Robert. 1995. Sequencing and nesting in contingent valuation surveys. Journal of Environmental Economics and Management 28:155-173.

Carson, R., W. Hanemann, R. Kopp, J. Krosnick, R. Mitchell, S. Presser, P. Ruud, K. Smith, M. Conaway, and K. Martin. 1997. Temporal reliability of estimates from contingent valuation. Land Economics 73:151-163.

Cerda, A., M. Riofrío, and F. Vial. 1997. Valoración contingente para la creación de la Reserva "Shangri-La", en la VIII Región Chile. Lecturas de Economía, Universidad de Antioquia, $N^{\circ} 47$ : 47-65.

Champ, P., N. Flores, T. Brown, and J. Chivers. 2002. Contingent valuation and incentives. Land Economics 78:591-604.

Clark, J., and L. Friesen. 2008. The causes of order effects in contingent valuation survey: An experimental investigation. Journal of Environmental Economics and Management 56:195-206.

Del Saz Salazar, S., S. Hernández, and S. Garrido. 
2009. Estimación del valor económico de la calidad del agua de un río mediante una doble aproximación: una aplicación de los principios económicos de la Directiva Marco del Agua. Ciencia e Investigación Agraria 9:37-63.

Parra, C. 1989. El Control de la eutroficación de la Laguna Chica de San Pedro: Un caso de estudio. Ambiente y Desarrollo 5:117-136.

Herriges, J., and J. Shogren. 1996. Starting point bias in dichotomous choice valuation with Follow-Up questioning. Journal of Environmental Economics and Management 30:112-131.

Hoehn, J. 1991. Valuing the multidimensional impacts of environmental policy: Theory and Methods. American Journal of Agricultural Economics 73:289-299.

Hoevenagel, R. 1994. An assessment of the contingent valuation methods. p. 195 -227. In: Valuing the Environment: Methodological and Measurement Issues. Rüdiger Pethig (ed.). Kluwer Academic Publishers, Dordrecht, The Netherlands.

INE. 2003. Síntesis de Resultados Censo 2002. Clasificación Socioeconómica Urbana por Regiones, Provincias y Comunas. Instituto Nacional de Estadísticas (INE). Santiago, Chile.

INE. 2005. Ciudades, Pueblos, Aldeas y Caseríos. Instituto Nacional de Estadísticas (INE). Santiago, Chile.

Kahneman, D., and J. L. Knetsh. 1992. Valuing public goods: The purchase of moral satisfaction. Journal of Environmental Economics and Management 22:57-70.

Loomis, J., M. Lockwood, and T. DeLacy. 1993. Some empirical evidence on embedding effects in contingent valuation of forest protection. Journal of Environmental Economics and Managenment 24:45-55.

McDaniels, T., R. Gregory, J. Arvai, and R. Chuenpagdee. 2003. Decision structuring to alleviate embedding in environmental valuation. Ecological Economics 46:33-46.
Melo, O., and G. Donoso. 1995. Uso de encuestas de valoración contingente para valorar beneficios recreativos de Parques Urbanos: El Caso del Parque Bustamante. Serie de Investigación $N^{\circ} 68$. Departamento de Economía Agraria, Facultad de Agronomía e Ingeniería Forestal, Pontificia Universidad Católica de Chile. Santiago, Chile.

Mitchell, R., and R. Carson. 1989. Using surveys to value public good: The contingent valuation method. Resources for the Future. Washington DC, USA.

Parry, D., and R. Mendelsohn. 2005. Valuing air quality in Poland. Environmental and Resource Economics 30:131-163.

Pearce, D., and R. Turner. 1990. Economics of natural resource and the environment. Johns Hopkins University Press, Baltimore, USA.

Perman, R., Y. Ma, J. McGilvray, and M. Common. 1999. Natural resource and the environmental economics. Longman, Harlow, UK.

Shackley, P., and S. Dixon. 2000. Using contingent valuation to elicit public preferences for water fluoridation. Applied Economics 32:777-787.

Svedsäter, H. 2000. Contingent valuation of global environmental resources: Test of perfect and regular embedding. Journal of Economic Psychology 21:605-623.

Venkatachalam, L. 2004. The contingent valuation method: A review. Environmental Impact Assessment Review 24:89-124.

Vial, F., A. Cerda, and M. Riofrio. 1998. Contingent valuation and embedding effect: Some empirical and methodological issues and an application to wild areas protection in Chile. IDEAR Institute. Universidad Católica del Norte. Antofagasta, Chile.

Walsh, R., J. Loomis, and R. Gillman. 1984. Valuating option, existence and bequest demands for wilderness. Land Economics 60:14-29. 
